\title{
Accumulation during fruit development of components of interest in seed of Chia (Salvia hispanica L.) cultivar Oruro $\odot$ released in France $^{\underline{\mu}}$
}

\author{
Gwendoline Gravé ${ }^{1}$, Zéphirin Mouloungui ${ }^{1,}{ }^{*}$, Frederic Poujaud $^{2}$, Muriel Cerny ${ }^{1}$, Caroline Pauthe ${ }^{1}$, \\ Ibinga Sidrine Koumba ${ }^{1}$, Nikiema Diakaridja ${ }^{1}$ and Othmane Merah ${ }^{1,3}$ \\ ${ }^{1}$ Laboratoire de chimie agro-industrielle, LCA, université de Toulouse, INRA, Toulouse, France \\ 2 Panam-France Company, Les Grèzes, 544, route de Villebrumier, 3134 Villemur-sur-Tarn, France \\ ${ }^{3}$ Université Paul Sabatier, IUT A, département génie biologique, Auch, France
}

Received 13 May 2019 - Accepted 20 September 2019

\begin{abstract}
This study aimed to examine the accumulation of oil, fatty acids, sterols and tocopherols contents and compositions during fruit development on the new cultivar of Chia Oruro (Panam Cie, France) cultivated in France. This cultivar is the first released genotype in Europe and for cultivation in Europe. The experiment was conducted in 2017, in south-western France at the Regional centre for organic agriculture, at Auch (near Toulouse, South-West of France). Four samplings were made at 17, 24, 27 and 35 days after flowering (DAF). These dates of sampling correspond to stages 7-8 (fruit development and maturity) of BBCH scale. Oil content, fatty acid composition and sterols and tocopherols contents and profiles were determined. The highest levels of oil and tocopherols were reached at $27 \mathrm{DAF}$. In contrast, phytosterols content was highest at $17 \mathrm{DAF}(726.2 \mathrm{mg} /$ $100 \mathrm{~g}$ of oil) and decreased after this date. $\beta$-sitosterol was the main sterol in chia seed (63.4 to $89.1 \%$ of total sterols, depending of stage of fruit development). $\gamma$-tocopherol represented more than $92 \%$ of the total tocopherols present in the seed. High levels of polyunsaturated fatty acids ( 74.4 to $80 \%$ of total fatty acids) were observed in our study confirming those already reported in this species. High levels of saturated and monounsaturated fatty acids were reported at earlier stages and decreased gradually during fruit development. Polyunsaturated fatty acids followed an opposite trend. Their level was lowest at $17 \mathrm{DAF}(74.4 \%)$ and increased gradually to reach their higher level at $35 \mathrm{DAF}(80 \%)$. These results suggested clearly the interest to harvest and use of seed before entire maturity of the grain.
\end{abstract}

Keywords: Chia / fatty acids / phytosterols / tocopherols / fruit development / accumulation

Résumé - Accumulation des composants d'interêt durant le développement des fruits dans la graine du cultivar français Oruro $\odot$ de Chia (Salvia hispanica L.). Cette étude a examiné l'accumulation de l'huile, des acides gras, des stérols et des tocophérols durant le développement du fruit du nouveau cultivar de Chia Oruro (Panam Cie, France) cultivé en France. Ce cultivar est le premier génotype sélectionné en Europe et pour l'Europe. L'expérimentation a été réalisée en 2017, dans le sud-ouest de la France, au Centre régional d'expérimentation en agriculture biologique, à Auch (près de Toulouse, dans le sud-ouest de la France). Quatre prélèvements ont été effectués 17, 24, 27 et 35 jours après la floraison (DAF). Ces dates d'échantillonnage correspondent aux stades 7-8 (développement du fruit et maturité) de l'échelle BBCH. La teneur en huile, la composition en acides gras et les teneurs et profils en stérols et en tocophérols ont été déterminés. Les teneurs les plus élevées d'huile et de tocophérols ont été atteintes à 27 DAF. Au contraire, la teneur en phytostérols était la plus élevée à $17 \mathrm{DAF}(726,2 \mathrm{mg} / 100 \mathrm{~g}$ d'huile) et a diminué après cette date. Le $\beta$-sitostérol a été le principal stérol contenu dans les graines de chia $(63,4$ to $89,1 \%$ des stérols totaux et en fonction du stade de développement du fruit). Le $\gamma$-tocophérol représente plus de $92 \%$ du total des tocophérols présents dans la graine. Des teneurs élevées d'acides gras polyinsaturés ( 74,4 à $80 \%$ des acides gras totaux) ont été observées dans notre étude, ce qui confirme celles déjà signalées chez cette espèce. Des

\footnotetext{
Contribution to the Topical Issue "Lipids and health / Lipides et santé"

*Correspondence: zephirin.mouloungui@ensiacet.fr
} 
teneurs plus élevées d'acides gras saturés et mono-insaturés ont été observées aux stades précoces du développement $\mathrm{du}$ fruit et ont diminué progressivement au cours de la maturation. Les acides gras polyinsaturés ont suivi une tendance opposée. Leur niveau était le plus bas à $17 \mathrm{DAF}(74,4 \%)$ et a augmenté progressivement pour atteindre leur niveau supérieur à $35 \mathrm{DAF}(80 \%)$. Ces résultats suggèrent clairement l'intérêt de récolter et d'utiliser les graines avant leur maturité complète.

Mots clés : Chia / acides gras / phytostérols / tocophérols / développement du fruit / accumulation

\section{Introduction}

Chia (Silvia hispanica L.), a Lamiaceae species, is an ancient Central American crop (Capitani et al., 2012) recently promoted as a functional food and known as source of omega3 and omega- 6 . Chia seeds contain more than $30 \%$ of oil $(310 \mathrm{~g} / \mathrm{kg}$ of seeds) and, particularly, a high proportion of unsaturated fatty acids present (PUFA: $82.0 \%$ and MUFA $6.9 \%$ ). Chia oil also contains high levels of tocopherols and sterols (Ciftçi et al., 2012). The proportions of these active compounds in chia seeds depend on several factors. Environmental differences, climatic change, the availability of essential nutrients, genotype, year of cultivation and soil type all play a crucial role in determining seed composition (Ayerza and Coates, 2009). For instance, protein levels decrease with increasing temperature (Ayerza and Coates, 2011). An inverse relationship has also been found between altitude and saturated fatty acid (SFA) levels. At low altitude, the proportion of SFA is higher in areas of higher temperature (Ayerza, 2010). In Argentina, temperature was found to influence greatly the fatty acids composition of chia oil (Ayerza, 1995). Seed coat, growing locations, genotypes were found to influence oil content, fatty acid composition of chia seed (Ayerza, 1995, 2010; Ayerza and Coates, 2009, 2011), which allowed to propose the use of these traits as criteria to determine the commercially origin of seeds of chia (Ayerza and Coates, 2011). Moreover, evolution of the quality of chia during plant growth was studied for its interest as forage in green plant part (Peiretti and Meineri, 2008). During plant development, in South America, from April to May, an increase in ambient temperature triggered a decrease in polyunsaturated fatty acid (PUFA) levels in vegetative plant parts. In Europe, studies performed from May to September, showed a modification of PUFA according genotypes and location (Grimes et al., 2018). The amount of alpha-linolenic acid (ALA) ( $\omega 3$ ) has been shown to decrease by $23 \%$ from early development to the budding stage. This decrease is accompanied by increases in linoleic acid (LA) ( $\omega 6)$ and lignin levels (Peiretti and Meineri, 2008). No information is available on the variation of fatty acid composition during fruit development of chia. Moreover, all the previous studies were carried out in South America. Few studies have been already performed for Chia cultivation in Europe using some genotypes released in America (Bochicchio et al., 2015; Grimes et al., 2018; Karkanis et al., 2018). These works revealed the possibilities to cultivate, in Europe, some genotypes released in South America. Therefore, the aim of this work is to study the accumulation of oil, fatty acids composition, sterols and tocopherols content and composition during seed filling and maturation of one cultivar of Chia released in France in France.

\section{Materials and methods}

\subsection{Plant material, trial and environmental conditions}

Seeds of chia, genotype Oruro®, were provided by PANAM Cie (Villemur, France). The experiment was conducted in 2017, in south-western France at the Regional Centre for Organic Agriculture, at Auch (near Toulouse, southwest France, $\left.43^{\circ} 38^{\prime} 47^{\prime \prime} \mathrm{N}, 0^{\circ} 35^{\prime} 08^{\prime \prime} \mathrm{E}\right)$. Field trial was carried out on a deep limestone clay silt soil with high water-holding capacity. The trial was sown at a density of 40 seeds by $\mathrm{m}^{2}$ on June 6th, with $0.6 \mathrm{~m}$ between rows and at $1 \mathrm{~cm}$ of depth. The crops were completely managed under organic and rainfed conditions without any chemical supply. Crushed feathers were applied as an organic $\mathrm{N}$ fertiliser at a rate of 60 units ha $^{-1}$. Weeds were eliminated mechanically. Flowering occurred at end August and maturity took place at the end of September. Four samplings were made at 17 (71-73 BBCH stages), (Hack et al., 1992), 24 (77 and $78 \mathrm{BBCH}$ stages), 27 (80 and $81 \mathrm{BBCH}$ stages) and $35(83-84 \mathrm{BBCH}$ stages) days after flowering (DAF). Sampling at full maturity was not released.

Table 1 presents rainfall and temperatures during the plant cycle and were compared to the weather data of the last 55 years. This comparison was done in order to explain that climatic conditions prevailed during 2017 were, almost as a "model year" of the last half century. Indeed, amount of rainfall in 2017 was quite similar to those recorded during 55 years in the same area. In contrast, the beginning of the cycle was $0.5^{\circ} \mathrm{C}$ warmer than the half century temperature (Tab. 1).

\subsection{Extraction and determination of fatty acid and sterol contents and compositions}

Fatty acids were determined according to a method based on the oil solubility in cyclohexane and the transformation of fatty acids to their methyl esters (norm ISO 5509: 1990). Whole seeds $(1 \mathrm{~g})$ were ground with $10 \mathrm{~mL}$ of cyclohexane. After centrifugation at $10000 \mathrm{~g}$ during 15 minutes, the organic phase is set aside and two others extractions are realised. Organic phases are met and filtered on anhydrous $\mathrm{Na}_{2} \mathrm{SO}_{4}$. Filtrate is dried by nitrogen flow The fatty acid profile of the triglycerides present in the oil was determined after transmethylation with TMSH (0.2 M trimethylsulfonium hydroxide in methanol) according to AFNOR Method NF EN ISO 12966-3. The fatty acids methyl esters (FAME) obtained by this transesterification reaction were analyzed with a gas chromatograph (Roche et al., 2006) equipped with a CP-select CB column (50 m long, $0.32 \mathrm{~mm}$ i.d., $0.25 \mu \mathrm{m}$ film thickness); helium was used as the carrier gas, at a flow rate of $1.2 \mathrm{~mL} / \mathrm{min}$; split injector $(1: 100)$ and FID were maintained at $250{ }^{\circ} \mathrm{C}$; the initial oven temperature was set at $185^{\circ} \mathrm{C}$ for $40 \mathrm{~min}$, increased 
Table 1. Mean monthly temperatures and rainfall during the cropping season of 2017 and average of 55 years in Auch (near Toulouse, South West of France).

\begin{tabular}{|c|c|c|c|c|}
\hline Month & \multicolumn{2}{|c|}{ Rainfall (mm) } & \multicolumn{2}{|c|}{ Temperature $\left({ }^{\circ} \mathrm{C}\right)$} \\
\hline June & 65,3 & 61,1 & 21,8 & 18,9 \\
\hline July & 35,3 & 47,1 & 21,7 & 21,5 \\
\hline August & 57,2 & 58,3 & 22,1 & 21,3 \\
\hline September & 52,9 & 55,9 & 16,7 & 18,5 \\
\hline December & 92,9 & 68,1 & 6,1 & 6,2 \\
\hline Mean June-Oct & & & 19,46 & 18,92 \\
\hline Sum June-Oct & 271,1 & 279,2 & & \\
\hline Mean Aug-Sept & & & 19,4 & 19,9 \\
\hline Sum Aug-Sept & 110,1 & 114,2 & & \\
\hline
\end{tabular}

to $250{ }^{\circ} \mathrm{C}$ at a rate of $15^{\circ} \mathrm{C} / \mathrm{min}$ and maintained at this temperature for $10 \mathrm{~min}$. Sterol content was determined by gas chromatography (Roche et al., 2010a). We introduced $50 \mu \mathrm{L}$ of a $2 \mathrm{mg} / \mathrm{mL}$ solution of cholestanol in chloroform in to a $15 \mathrm{~mL}$ screw top tube. The chloroform was then eliminated by evaporation. A test run was then carried out with the addition of $100 \mathrm{mg}$ of oil to the tube, followed by $2 \mathrm{~mL}$ of $1 \mathrm{M} \mathrm{KOH}$ in ethanol. The mixture was vortexed and heated at $75^{\circ} \mathrm{C}$ in a water bath for $30 \mathrm{~min}$. It was then allowed to cool to room temperature; $1 \mathrm{~mL}$ of distilled water was added and the mixture was vortexed. The unsaponifiable material was then extracted in $6 \mathrm{~mL}$ of cyclohexane. We collected $160 \mu \mathrm{L}$ of the cyclohexane phase, which we then silylated by adding $40 \mu \mathrm{L}$ of BSTFA/TMCS (99/1 mixture). The sample was heated for a few minutes at $103{ }^{\circ} \mathrm{C}$ and then $1 \mu \mathrm{L}$ was injected into a Perkin-Elmer gas chromatograph equipped with an Agilent VF-5ms column (30 m long, internal diameter of $0.25 \mathrm{~mm}$, film thickness of $0.25 \mu \mathrm{m}$ ) and coupled to a flame ionization detector operating at $355^{\circ} \mathrm{C}$. The carrier gas was helium, at a column head pressure of $100 \mathrm{kPa}$. The thermal conditions were as follows: $55^{\circ} \mathrm{C}$ for $0.5 \mathrm{~min}$, an increase in temperature of $200^{\circ} \mathrm{C} / \mathrm{min}$ to $340{ }^{\circ} \mathrm{C}$, then maintenance at $340^{\circ} \mathrm{C}$ for $30^{\circ} \mathrm{min}$ for the injector; $160^{\circ} \mathrm{C}$ for $0.5 \mathrm{~min}$, then an increase of $20^{\circ} \mathrm{C} / \mathrm{min}$ to $260^{\circ} \mathrm{C}$, then of $2{ }^{\circ} \mathrm{C} / \mathrm{min}$ to $300^{\circ} \mathrm{C}$ and $45^{\circ} \mathrm{C} / \mathrm{min}$ to $350{ }^{\circ} \mathrm{C}$ for the oven. The various sterols were identified by comparing their retention times with those of commercial standards or reference values. The sterols were quantified against an internal standard.

Tocopherol content was determined by high-performance liquid chromatography. We solubilized $10 \mathrm{mg}$ of oil in $1 \mathrm{~mL}$ of cyclohexane. We then injected $20 \mu \mathrm{L}$ of the resulting solution into a liquid chromatography system (Dionex) equipped with a Kromasil 100 SIL $5 \mu$ column (250 mm long, with an internal diameter of $4 \mathrm{~mm}$ ). A mixture of $99.5 \%$ isooctane and $0.5 \%$ isopropanol $(\mathrm{v} / \mathrm{v})$ was used as the mobile phase, at a flow rate of $1.1 \mathrm{~mL} / \mathrm{min}$. Tocopherols were detected with a fluorimeter (Dionex), with an excitation wavelength of $290 \mathrm{~nm}$ and an emission wavelength of $317 \mathrm{~nm}$. The tocopherols present in the oil were quantified against an external standard, and were identified by a comparison of retention times with those of reference standards.

\subsection{Statistical data analysis}

Statistical analyses were carried out on all the plots with three analytical replications. Analyses of variance and Duncan tests for means comparison between seed development stages were applied. The statistical analyses were performed using a statistical package (Sigmastat Version 2.0, USA).

\section{Results and discussion}

\subsection{Oil yield}

Table 2 presents oil content and fatty acid composition during seed fruit development of chia. Oil yield of chia seed has been found to vary between $23.3 \%-28.4 \%$ at different stages of seed fruit development (Tab. 2). Oil content increased gradually fruit development and reached the highest value at 27 days after flowering (DAF). Nevertheless, this value decreased slightly at $35 \mathrm{DAF}$. This result obtained under organic cultivation are quite in the range of values already reported for different genotypes cultivated in South America (Ayerza, 1995, 2010; Ayerza and Coates, 2009, 2011) or obtained by different extraction methods (Sayed-Ahmad, 2018) or by using different solvents (Segura-Campos et al., 2014). Recent study conducted in Germany revealed higher oil yield than in our study (Grimes et al., 2018). This result could be explained by genotypic, environmental factor, as well as method and solvent of extraction. Indeed, the genotype and locations of cultivation differed from their climatic conditions. Moreover, Grimes et al. (2018) used hexane while, cyclohexane was used in our study. This difference of chemical structure may induce difference in oil extraction (Oladipo and Betiku, 2019). Since, the seeds were harvested before full maturation, the slight decrease of oil content observed at 35 DAF could be, probably, due to respiration losses (Roche et al., 2016; Belo et al., 2018). Accumulation of oil in oilseed crops is regulated by the "Fatty Acid Synthetase" enzymatic system, which achieves differently during fruit development phases. Thus, at earlier phases, the FA-Synthetase system was induced, and oil content was increased. When oil content reached the plateau phase, these enzymes were less active and 
Table 2. Fatty acids (\%) and oil (\%) accumulation during seed ripening of chia seed in 2017.

\begin{tabular}{|c|c|c|c|c|}
\hline Fatty acid $(\%)$ & \multicolumn{4}{|c|}{ Days after flowering } \\
\hline OY & $23.3 \mathrm{~d}$ & $26.9 \mathrm{c}$ & $28.4 \mathrm{a}$ & $27.4 \mathrm{~b}$ \\
\hline \multicolumn{5}{|c|}{ Saturated fatty acids (SFA) } \\
\hline $\mathrm{C} 16: 0$ & $9.2 \pm 0.0 \mathrm{a}$ & $8.4 \pm 0.1 b$ & $8.2 \pm 0.0 \mathrm{~b}$ & $8.3 \pm 0.1 b$ \\
\hline $\mathrm{C} 18: 0$ & $4.0 \pm 0.0 \mathrm{a}$ & $3.4 \pm 0.0 \mathrm{c}$ & $3.7 \pm 0.0 \mathrm{~b}$ & $3.4 \pm 0.0 \mathrm{c}$ \\
\hline \multicolumn{5}{|c|}{ Monounsaturated fatty acids (MUFA) } \\
\hline $\mathrm{C} 18: \ln 7$ & $1.1 \pm 0.0 \mathrm{c}$ & $1.0 \pm 0.0 \mathrm{c}$ & $7.7 \pm 0.0 \mathrm{a}$ & $7.4 \pm 0.1 b$ \\
\hline $\mathrm{C} 18: \ln 9$ & $11.3 \pm 0.1 \mathrm{a}$ & $7.7 \pm 0.1 b$ & $0.9 \pm 0.0 \mathrm{c}$ & $1.0 \pm 0.0 \mathrm{c}$ \\
\hline Total & $12.4 \pm 0.1 \mathrm{a}$ & $8.7 \pm 0.1 b$ & $8.7 \pm 0.0 \mathrm{~b}$ & $8.4 \pm 0.1 \mathrm{c}$ \\
\hline \multicolumn{5}{|c|}{ Polyunsaturated fatty acids (PUFA) } \\
\hline C18:2n6 & $22.0 \pm 0.1 \mathrm{a}$ & $19.9 \pm 0.1 \mathrm{c}$ & $20.4 \pm 0.1 b$ & $20.0 \pm 0.1 \mathrm{c}$ \\
\hline $\mathrm{C} 18: 3 \mathrm{n} 3$ & $52.4 \pm 0.2 \mathrm{c}$ & $59.6 \pm 0.2 \mathrm{a}$ & $59.0 \pm 0.0 \mathrm{~b}$ & $60.0 \pm 0.3 \mathrm{a}$ \\
\hline Water content $(\%)$ & $63.1 \pm 1.2 \mathrm{a}$ & $52.7 \pm 1.0 \mathrm{~b}$ & $39.0 \pm 1.1 \mathrm{c}$ & $25.2 \pm 0.9 \mathrm{c}$ \\
\hline
\end{tabular}

Data were means \pm SD of three replicates. C16:0 (Palmitic acid); C18:0 (Stearic acid); C18:1n7 (vaccenic acid); C18:1n9c (oleic acid); C18: 2n6c (linoleic acid); C18:3n3 a (linolenic acid); SFA/UFA (ratio saturated/unsaturated fatty acids); $\omega 3 / \omega 6$ (ratio linolenic acid/linoleic acid); OY (oil yield). In same line, means with the same letter are not significantly different at 0.05 probability.

less efficient; this in turn reduced the rate of oil accumulation (Msaada et al., 2009; Nguyen et al., 2015).

\subsection{Fatty acid composition}

Two saturated (palmitic and stearic acids), two monounsaturated (vaccenic and oleic acids) and two polyunsaturated (linoleic and linolenic acids) fatty acids were detected during chia fruit development (Tab. 2). Saturated fatty acids (SFA) constituted $13 \%$ of total fatty acids at $17 \mathrm{DAF}$, and decreased to reach $11.6 \%$ at $35 \mathrm{DAF}$. This decrease was more marked for the monounsaturated fatty acids (MUFA). Indeed, this trait decreased by $30 \%$ between 17 and 35 DAF (Tab. 2). In contrast, polyunsaturated fatty acids (PUFA) increased from $74 \%$ (at $17 \mathrm{DAF}$ ) to $80 \%$ (at $35 \mathrm{DAF}$ ). Linolenic acid, linoleic, oleic stearic and palmitic acids were the major fatty acids (Tab. 2). Nevertheless, the fatty acids accumulation did follow neither the same trend nor the same speed. Indeed, at earlier stages of fruit development (17 DAF), palmitic, stearic, oleic and linoleic acids were at their higher level in the seed. The content of these fatty acids declined to reach its lowest level around the 35 th day after flowering. Moreover, while stearic, palmitic and linoleic acids decreased slightly oleic acid declined more than ten times between 17 and 35 DAF (Tab. 2). In the same time, linolenic and vaccenic acids followed the opposite path with a progression of their content to reach the highest content between 27 and $35 \mathrm{DAF}$ (Tab. 2). The ratio of $\omega 6 / \omega 3$ followed similar trend. In fact, this ratio was highest at $17 \mathrm{DAF}$ and decreased rapidly to reach a plateau at $24 \mathrm{DAF}$ (Tab. 2). Similar trends have been reported in other species from different botanical families (Hamrouni-Sellami et al., 2007; Msaada et al., 2009, Sriti et al., 2011; Nguyen et al., 2015; Roche et al., 2016). The ratio of unsaturated to saturated fatty acids increased markedly from 6.6 (17DAF) to 7.5 (24 DAF) and remained constant until complete maturity. These values are similar to those reported recently in Germany (Grimes et al., 2018).

The fatty acids' accumulation seems to follow the biosynthesis dynamics as described in Kennedy pathway evolved acyl-CoA elongase and desaturases enzymes that could explain the decrease of saturated FA which served to synthetize polyunsaturated fatty acids. Moreover, in our study linoleic acid level was nearly $15 \%$ higher than results reported previously (Ayerza, 1995, 2010; Ayerza and Coates, 2009, 2011; Ciftçi et al., 2012). This difference could be due to genotype and climatic conditions. Indeed, Oruro is newly released genotype which was cultivated in France for the first time. The ratio of SFA/MUFA increased by more $40 \%$ (Tab. 2) from 17 to $24 \mathrm{DAF}$, while SFA/PUFA ratio decreased for the same period from 0.18 to 0.15 . Both ratios remained constant until maturity (Tab. 2). These values are similar to those reported recently in Germany (Grimes et al., 2018). Moreover, $\omega 3 / \omega 6$ ratio of the chia oils varied from 2.4 (17 DAF) to 3.0 (24-35 DAF) during the fruit development. These values are in lines with those previously reported results even in other growth conditions and other genotypes (Ayerza, 1995, 2010; Ayerza and Coates, 2009, 2011; Grimes et al., 2018; SayedAhmad, 2018). These values are significantly higher than those of most vegetable oils, e.g. canola oil $(0.36)$, olive oil $(0.08$ $0.12)$, soybean oil (0.15), Safflower (0.01) Atlas pistachio (0.10) and walnut oil (0.25) (Galão et al., 2014; Ojeda-Amador et al., 2018; Rodrigues et al., 2018; Beyzi et al., 2019; Labdelli et al., 2019; Roche et al., 2019). The tocopherol content increased in same way between 17 to $24 \mathrm{DAF}$ (Tab. 3). It is well known that these molecules act as antioxidant in order to protect lipids oxidation. This could explain the concomitant 
Table 3. Phytosterol and tocopherols accumulation during seed ripening of chia seed in 2017 .

\begin{tabular}{llll}
\hline $\begin{array}{l}\text { Days after flowering (DAF) } \\
\text { Phytosterols (mg/100g of oil) }\end{array}$ & 17 & 24 & 27 \\
Campesterol & $99.7 \pm 0.6 \mathrm{a}$ & $92.2 \pm 0.8 \mathrm{~b}$ & $85.7 \pm 1.6 \mathrm{c}$ \\
Stigmasterol & $42.5 \pm 0.3 \mathrm{a}$ & $37.5 \pm 0.9 \mathrm{~b}$ & $34.1 \pm 0.6 \mathrm{c}$ \\
$\beta$-Sitosterol & $460.7 \pm 4.3 \mathrm{a}$ & $454.3 \pm 7.6 \mathrm{a}$ & $431.2 \pm 6.1 \mathrm{~b}$ \\
$\Delta$-5 Avenasterol & $46.8 \pm 2.9 \mathrm{a}$ & $39.7 \pm 0.1 \mathrm{~b}$ & $39.9 \pm 1.5 \mathrm{~b}$ \\
Total Desmethylsterols & $649.7 \pm 5.9 \mathrm{a}$ & $623.6 \pm 9.5 \mathrm{~b}$ & $590.9 \pm 8.7 \mathrm{c}$ \\
Gramisterol & $15.2 \pm 0.1 \mathrm{c}$ & $14.1 \pm 0.2 \mathrm{~d}$ & $17.2 \pm 0.1 \mathrm{a}$ \\
Citrostadienol & $16.3 \pm 0.3 \mathrm{~b}$ & $14.8 \pm 0.0 \mathrm{c}$ & $20.1 \pm 0.6 \mathrm{a}$ \\
Cycloartenol & $22.8 \pm 1.4 \mathrm{a}$ & $16.8 \pm 1.0 \mathrm{~b}$ & $17.4 \pm 0.7 \mathrm{~b}$ \\
Methylen Cycloartanol & $22.2 \pm 1.2 \mathrm{a}$ & $15.11 \pm 0.5 \mathrm{~d}$ & $17.9 \pm 0.8 \mathrm{~b}$ \\
Total Di and Methylsterols & $76.5 \pm 2.8 \mathrm{a}$ & $60.8 \pm 1.4 \mathrm{c}$ & $72.5 \pm 1.5 \mathrm{a}$ \\
Total Sterols & $726.2 \pm 3.1 \mathrm{a}$ & $684.4 \pm 8.1 \mathrm{~b}$ & $663.5 \pm 9.2 \mathrm{c}$ \\
Days after flowering (DAF) & & & $15.9 \pm 0.2 \mathrm{~b}$ \\
Tocopherol (mg/100g of oil) & 17 & 24 & 27 \\
$\alpha$-tocopherol & $1.5 \pm 0.1 \mathrm{~b}$ & $1.8 \pm 0.1 \mathrm{a}$ & $18.9 \pm 1.4 \mathrm{~b}$ \\
$\gamma$-tocopherol & $38.8 \pm 1.8 \mathrm{~b}$ & $45.3 \pm 2.7 \mathrm{a}$ & $69.1 \pm 1.9 \mathrm{ab}$ \\
S-tocopherol & $1.6 \pm 0.0 \mathrm{c}$ & $1.7 \pm 0.2 \mathrm{~b}$ & $656.0 \pm 13.2 \mathrm{c}$ \\
Total tocopherols & $42.0 \pm 1.9 \mathrm{~b}$ & $48.8 \pm 3.0 \mathrm{a}$ & $47.9 \pm 0.6 \mathrm{a}$ \\
\hline
\end{tabular}

In same line, means with the same letter are not significantly different at 0.05 probability.

accumulation of both polyunsaturated fatty acids and tocopherols in same way.

Supply of chia seeds in alimentation on rat blood plasma resulted in significant reduction of triglycerides (TG) and lowdensity lipoproteins (LDL) were significantly reduced, while, high-density lipoproteins (HLD) and omega-3 (PUFA) have decreased (Ayerza and Coates, 2007; Fernandez et al., 2008). Relationships between fatty acids composition of diet and some diseases, like cardiovascular diseases or diabetes, have been extensively reported (Betti et al., 2009). This also true for chia seed (Nieman et al., 2009; Guevara-Cruz et al., 2012; Jin et al., 2012). Indeed, PUFA are necessary for the proper functioning of the brain, the eyes, and the entire nervous system and to prevent the risk of cardiovascular diseases (Corley and Tinker, 2003; Vedtofte et al., 2011). Mono and polyunsaturated present an effective action in lowering total cholesterol (Gretchen and Heather, 2014; Kratz et al., 2002), and reducing the risk of breast cancer (Kushi and Giovannucci, 2002). Moreover, linoleic acid helps to prevent human diseases, particularly cardiovascular disease, and certain disorders like Alzheimer's disease (Khan et al., 2015). The oil of chia is composed of $75 \%$ of mono and polyunsaturated fatty acids and therefore constitutes very healthy oil for human and could increases the lowering of risks of cardiovascular diseases. Furthermore, the recommendations of the FAO as well as Food and Alimentary national Agencies, concerning the ratio saturated to unsaturated and linoleic to linolenic acids, are clearly established (FAO, 2010; Kalonji et al., 2012; Schwingshackl and Hoffmann, 2012). Indeed, minimum intake values PUFA to prevent deficiency symptoms are estimated to be $2.5 \%$ of energy for linoleic acid plus $0.5 \%$ of energy for linolenic acid (FAO, 2010). For MUFA intakes, international recommendations vary greatly between $12-25 \%$. Moreover, the ratio of linoleic to linolenic must be lesser than five (Kalonji et al., 2012; Ristić-Medić et al., 2013; Labdelli et al., 2019). Our results showed, at $24 \mathrm{DAF}$, the chia seeds fulfill the recommendations mentioned above (Tab. 2). This fact reinforced the great interest to harvest and use seed of chia before maturity as reported in other studies (Msaada et al., 2009; Roche et al., 2010b, 2016; Sriti et al., 2011; Nguyen et al., 2015; Belo et al., 2018).

\subsection{Sterols and tocopherols contents and compositions}

Chia seeds contain between 656 and $726 \mathrm{mg} / 100 \mathrm{~g}$ of oil of total sterols. Eighty-nine percent of them are desmethylsterols represented mainly by $\beta$-sitosterol and campesterol at a level of $140 \mathrm{mg} / 100 \mathrm{~g} \mathrm{SDM}$ (Tab. 3). Sterols content observed in our study were quite higher than those reported by Ciftçi et al. (2012) Dabrowski et al. (2017) and Sayed-Ahmad (2018), who observed a range of $402-508 \mathrm{mg} .100 \mathrm{~mL}^{-1}$ of oil. These differences can be explained by both genotypic and environmental effect. As already presented, our study was based on a new cultivar developed in Europe and cultivated in France for the first time.

During seed filling and maturation of chia seeds phytosterols content was higher at $17 \mathrm{DAF}$ and followed the progressive and slight decrease to reach a minimum in the whole seed at 27 and 35 DAF (Tab. 3). Sterol concentration differed according to sterol category. Desmethylsterol concentration followed similar trend that total sterols and was the highest at 17 DAF. This result was expected since desmethylsterols represented more than $89 \%$ of total phytosterols (Tab. 3). In contrast, the concentration of dimethyl- and methylsterol content varied during grain filling with the highest values were observed at 17 and 27 DAF and the lowest ones at 24 DAF (Tab. 3). Methylencycloartanol and cycloartenol (dimethylsterol category) showed higher value at 17 DAF followed by a decrease (24 DAF) and an increase after this date. In the methylsterol category, citrostadienol and gramisterol content increased also until $27 \mathrm{DAF}$ then 
decreased until harvest (Tab. 3). Nevertheless, the dynamics of these two categories of sterols seems to be linked. Indeed, dimethylsterols serve as precursor for the synthesis of methylsterols (Merah et al., 2012). The decrease of dimethylsterols observed at $24 \mathrm{DAF}$ resulted in the increase of the level of methylsterols at $27 \mathrm{DAF}$, as reported in other species (Merah et al., 2012; Roche et al., 2016).

Tocopherols content and composition of chia during fruit development is presented in Tab. 3. Content of tocopherols varied slightly. High level of tocopherols was noticed along the fruit development. A slight decrease was observed at 24 DAF to increase again and reaching the highest value at $27 \mathrm{DAF}$. As for sterols, these results were higher than those reported in other works (Ciftçi et al., 2012; Dąbrowski et al., 2017; Sayed-Ahmad, 2018). The main isomer was $\gamma$ tochopherol that represented more than 92 of the total tocopherols as already reported by (Ciftçi et al., 2012; Sayed-Ahmad, 2018). In contrast, Dąbrowski et al. (2017), who used different methods of extraction, observed nearly 5 to $7 \%$ more $\gamma$ tochopherol than in our study.

The level of these compounds is not only dependent on extraction method (Dąbrowski et al., 2017), but also on genotype and environment (Sriti et al., 2011; Msaada et al., 2009; Roche et al., 2010b).

\section{Conclusion}

This work aimed to investigate the fatty acid, sterols compositions and oil accumulation in Chia (Salvia hispanica L.) seed, cultivar Oruro (C released in France, from onset of seed filling until maturation. This was the first report on bioaccumulation of oil and fatty acid in chia seed. Results demonstrated that the highest oil yield was achieved at $27 \mathrm{DAF}$. Fatty acid profile varied greatly during fruit development. Linolenic acid $(60 \%$ of total fatty acids at maturity) reached its higher level at 35 days after flowering. In addition, polyunsaturated fatty acids increased, whereas saturated and monounsaturated fatty acids decreased significantly during fruit development. The ratio of $\omega 6 / \omega 3$ was highest at $17 \mathrm{DAF}$ and lowest at $35 \mathrm{DAF}$. Therefore, if the objective is to decrease the $\omega 6 / \omega 3$ ratio of it will be preferable to harvest at $35 \mathrm{DAF}$ (which is not the full maturity in our study). In contrast, if the aim is to harvest higher oil content and higher tocopherol level, seed should be harvest at $27 \mathrm{DAF}$ or at full maturity. Our results highlighted the possibility to seeds of chia according their components concentration. Moreover, this requires the development of techniques for harvesting, storing and probably drying of fruits. These results need to be ascertained by other field experiments.

Acknowledgments. This work benefited from the support of the Occitanie Region, European support to through the Chia'Innov (RECH no. 16004168, 2017). The authors gratefully acknowledge C. Bonillo from the Mirandette experimental station in Masseube, Compagnie d'Aménagement des Coteaux de Gascogne (in Gascony, south of France) for his rigor and his help in the experiments.

\section{Author contributions}

Z.M. is the project Manager. Z.M. and O.M. conceptualization. G.G., M.C., C.P. and O.M developed the methodology and performed the experiments and the measurements. M.C., G.G. and C.P. assisted with measurements. O.M., G.G. and Z. $M$. contributed to the analysis and interpretation of the data. G. G. Z.M. and O.M. contributed to data collection and to the writing of the manuscript.

Conflicts of interest. The authors declare that they have no conflicts of interest in relation to this article.

\section{References}

Ayerza R. 1995. Oil content and fatty acid composition of chia (Salvia hispanica L.) from five northwestern locations in Argentina. $J$ Am Oil Chem Soc 72: 1079-1081.

Ayerza R. 2010. Effects of seed color and growing locations on fatty acid content and composition of two chia (Salvia hispanica L.) genotypes. J Am Oil Chem Soc 87: 1161-1165.

Ayerza R, Coates W. 2007. Effect of dietary alpha-linolenic fatty acid derived from chia when fed as ground seed, whole seed and oil on lipid content and fatty acid composition of rat plasma. Ann Nutr Metabol 51: 27-34. DOI: 10.1159/000100818.

Ayerza R, Coates W. 2009. Influence of environment on growing period and yield, protein, oil and $\alpha$-linolenic content of three chia (Salvia hispanica L.) selections. Ind Crops Prod 30: 321-324.

Ayerza R, Coates W. 2011. Protein content, oil content and fatty acid profiles as potential criteria to determine the origin of commercially grown chia (Salvia hispanica L.). Ind Crops Prod 34: 1366-1371.

Belo RG, Velasco L, Nolasco SM, Izquierdo NG. 2018. Dynamics of phytosterols content and concentration in sunflower grains. Crop Pasture Sci 69: 724-732.

Betti M, Perez TI, Zuidhof MJ, Renema RA. 2009. Omega-3-enriched broiler meat: 3. Fatty acid distribution between triacylglycerol and phospholipid classes. Poultry Sci 88: 1740-1754.

Beyzi E, Gunes A, Buyukkilic Beyzi S, Konca Y. 2019. Changes in fatty acid and mineral composition of rapeseed (Brassica napus ssp. oleifera L.) oil with seed sizes. Ind Crops Prod 129: 10-14.

Bochicchio R, Phillips TD, Lovelli S, et al. 2015. Innovative crop productions for healthy food: the case Chia (Salvia hispanica L.). In: Vastola A, ed. The sustainability of agro-food and natural resource systems in the Mediterranean Basin. Basel, Switzerland: Springer International Publishing, pp. 29-45.

Capitani MI, Spotorno V, Nolasco SM, Tomás MC. 2012. Physicochemical and functional characterization of by-products from chia (Salvia hispanica L.) seeds of Argentina. LWT-Food Sci Technol 45: 94-102.

Ciftçi ON, Przybylski R, Rudzińska M. 2012. Lipid components of flax, perilla, and chia seeds. Eur J Lipid Sci Technol 114: 794-800.

Corley RHV, Tinker PB. 2003. The oil palm. 4th ed. Oxford, Malden MA: Blackwell Science.

Dąbrowski G, Konopka I, Czaplicki S, Tańska M. 2017. Composition and oxidative stability of oil from Salvia hispanica L. seeds in relation to extraction method. Eur J Lipid Sci Technol 119: $1-9$.

FAO. 2010. Fats and fatty acids in human nutrition. Report of an expert consultation, 10-14 November 2008 in Geneva. Rome: Food and Agriculture Organization of the United Nations.

Fernandez I, Vidueiros SM, Ayerza R, Coates W, Pallaro A. 2008. Impact of chia (Salvia hispanica L.) on the immune system: preliminary study. Proc Nutr Soc 67. DOI: 10.1017/S0029665108006216.

Galão OF, Carrão-Panizzi MC, Mandarino JMG, et al. 2014. Differences of fatty acid composition in Brazilian genetic and 
conventional soybeans (Glycine $\max$ (L.) Merrill) grown in different regions. Food Res Int 62: 589-594.

Guevara-Cruz M, Tovar AR, Aguilar-Salinas CA, et al. 2012. A dietary pattern including nopal, chia seed, soy protein, and oat reduces serum triglycerides and glucose intolerance in patients with metabolic syndrome. J Nutr 142: 64-69.

Gretchen V, Heather R. 2014. Position of the Academy of nutrition and dietetics: dietary fatty acids for healthy adults. J Acad Nutr Diet 114: 136-153.

Grimes SJ, Phillips TD, Hahn V, Capezzone F, Graeff-Hönninger S. 2018. Growth, yield performance and quality parameters of three early flowering Chia (Salvia hispanica L.) genotypes cultivated in Southwestern Germany. Agriculture 8: 154. DOI: 10.3390/agriculture8100154.

Hack H, Bleiholder H, Buhr L, et al. 1992. Einheitliche Codierung der phänologischen Entwicklungsstadien mono- und dikotyler Pflanzen - Erweiterte BBCH-Skala. Allgemein -. Nachrichtenbl. Deut. Pflanzenschutzd 44: 265-270.

Hamrouni-Sellami I, Salah HB, Kchouk ME, Marzouk B. 2007. Variations in phytosterol composition during the ripening of Tunisian safflower (Carthamus tinctorius L.) seeds. Pakistan $J$ Biol Sci 10: 3829-3834.

Jin F, Nieman DC, Sha W, Xie G, Qiu Y, Jia W. 2012. Supplementation of milled chia seeds increases plasma ALA and EPA in postmenopausal women. Plant Foods Hum Nutr 67: 105-110.

Kalonji E, Margaritis I, Morise A, Legrand P. 2012. Une nouvelle approche scientifique pour l'actualisation des références nutritionnelles en acides gras. Réalités cardiologiques. Rev Gen 4: 1-11.

Karkanis AC, Kontopoulou CK, Lykas C, Kakabouki I, Petropoulos SA, Bilalis D. 2018. Efficacy and selectivity of pre- and postemergence herbicides in chia (Salvia hispanica L.) under Mediterranean semi-arid conditions. Notulae Botanicae Horti Agrobotanici Cluj-Napoca 46: 183-189.

Khan S, Choudhary S, Pandey A, Khan MK, Thomas G. 2015. Sunflower oil: efficient oil source for human consumption. Emerg Life Sci Res 1(1): 1-3.

Kratz M, Cullen P, Kannenberg F, et al. 2002. Effects of dietary fatty acids on the composition and oxidizability of low-density lipoprotein. Eur J Clin Nutr 56: 72-81.

Kushi L, Giovannucci E. 2002. Dietary fat and cancer. Am J Med Sci 113(9): 63s-70s.

Labdelli A, Zemour K, Simon V, Cerny M, Adda A, Merah O. 2019. Pistacia atlantica Desf., a source of healthy vegetable oil. Appl Sci 9: 2552. DOI: 10.3390/app9122552.

Merah O, Langlade N, Alignan M, et al. 2012. Genetic control of phytosterol content in sunflower seeds. Theoret Appl Genet 125: 1589-1601.

Msaada K, Hosni K, Ben Taarit M, Chahed T, Hammami M, Marzouk B. 2009. Effects of growing region and maturity stages on oil yield and fatty acid composition of coriander (Coriandrum sativum L.) fruit. Sci Horticult 120: 525-531.

Nguyen QH, Talou T, Cerny M, Merah O. 2015. Oil and fatty acid accumulation during coriander (Coriandrum sativum L.) fruit ripening under organic agriculture. Crop J 3: 366-369.
Nieman DC, Cayea EJ, Austin MD, Henson DA, McAnulty SR, Jin F. 2009. Chia seed does not promote weight loss or alter disease risk factors in overweight adults. Nutr Res 29: 414-418.

Ojeda-Amador RM, Salvador MD, Gómez-Alonso S, Fregapane G. 2018. Characterization of virgin walnut oils and their residual cakes produced from different varieties. Food Res Int 108: 396-404.

Oladipo B, Betiku E. 2019. Process optimization of solvent extraction of seed oil from Moringa oleifera: an appraisal of quantitative and qualitative process variables on oil quality using D-optimal design. Biocatal Agricult Biotechnol 20: 101187. DOI: 10.1016/j. bcab.2019.101187.

Peiretti PG, Meineri G. 2008. Effects on growth performance, carcass characteristics, and the fat and meat fatty acid profile of rabbits fed diets with chia (Salvia hispanica L.) seed supplements. Meat Sci 80: 1116-1121.

Ristić-Medić D, Vučić V, Takić M, Karadžić I, Glibetić M. 2013. Polyunsaturated fatty acids in health and disease. J Serbian Chem Soc 78: 1269-1289.

Roche J, Alignan M, Bouniols A, Cerny M, Mouloungui Z, Merah O. 2010a. Sterol concentration and distribution in sunflower seeds (Helianthus annuus L.) during seed development. Food Chem 119: 1451-1456.

Roche J, Alignan M, Bouniols A, et al. 2010b. Sterol content in sunflower seeds (Helianthus annuus L.) as affected by genotypes and environmental conditions. Food Chem 121: 990-995.

Roche J, Bouniols A, Cerny M, Mouloungui Z, Merah O. 2016. Fatty acid and phytosterol accumulation during seed ripening in three oilseed species. Int J Food Sci Technol 51: 1820-1826.

Roche J, Mouloungui Z, Cerny M, Merah O. 2019. Effect of sowing date on fatty acid and phytosterols patterns of carthamus tinctoria L. Appl Sci 9(14): 2839. DOI: 10.3390/app9142839.

Rodrigues N, Casal S, Peres AM, et al. 2018. Effect of olive trees density on the quality and composition of olive oil from cv. Arbequina. Sci Horticult 238: 222-233.

Sayed-Ahmad B. Étude de l'agro-raffinage de graines d'apiaceae, Lamiaceae et Chenopodiaceae pour la production de molécules biosourcées en vue d'application en industrie cosmétique. Thèse de Doctorat, INP Toulouse, 2018. 257 p.

Schwingshackl L, Hoffmann G. 2012. Monounsaturated fatty acids and risk of cardiovascular disease: synopsis of the evidence available from systematic review and meta-analyses. Nutrients 4 : 1989-2007.

Segura-Campos MR, Ciau-Solís N, Rosado-Rubio G, Chel-Guerrero L, Betancur-Ancona D. 2014. Chemical and Functional Properties of Chia Seed (Salvia hispanica L.) Gum. Int J Food Sci ID 241053, 1-5.

Sriti J, Talou T, Faye M, Vilarem G, Marzouk B. 2011. Oil extraction from coriander fruits by extrusion and comparison with solvent extraction processes. Ind Crops Prod 33: 659-664.

Vedtofte MS, Jakobsen MU, Lauritzen L, Heitmann BL. 2011. Dietary $\alpha$-linolenic acid, linoleic acid, and n-3 long-chain PUFA and risk of ischemic heart disease. Am J Clin Nutr 94: 1097-1103.

Cite this article as: Gravé G, Mouloungui Z, Poujaud F, Cerny M, Pauthe C, Koumba IS, Diakaridja N, Merah O. 2019. Accumulation during fruit development of components of interest in seed of Chia (Salvia hispanica L.) cultivar Oruro@ released in France. OCL 26: 50. 